\title{
EFFECT OF POPULATION DENSITY ON NUMBER OF LEUKOCYTES IN DOMESTIC CATS
}

\author{
Sergey V. Naidenko ${ }^{1, *}$, Polina S. Klyuchnikova ${ }^{1}$, Vadim E. Kirilyuk ${ }^{1,2}$, Galina S. Alekseeva ${ }^{1}$ \\ ${ }^{1} A . N$. Severtsov Institute of Ecology and Evolution of RAS, Russia \\ ${ }^{2}$ Daursky State Nature Biosphere Reserve, Russia \\ *e-mail: snaidenko@mail.ru
}

Received: 30.08.2019. Revised: 20.04.2020. Accepted: 22.04.2020.

\begin{abstract}
Leukocytes (white blood cells) are an important part of the mammalian immune system preventing the invasion and colonisation by different pathogens. Many factors may affect the number of leukocytes in mammals, including the population density. The population density in the same species of felines may differ 100-300 times and the aim of this study was to estimate an effect of this factor on the leukocytes number and the ratio for two groups of domestic cats (Felis catus) with different population densities. We sampled 47 cats in the surroundings of Daursky State Nature Reserve, counted the number of leukocytes with a microscope immediately upon sampling and the leukocytes formula in the blood smears later in the laboratory. The population density of cats in the village and at herdsman stations differs approximately by 330 times. Domestic cats in the village (with a denser population) had a higher number of leukocytes and neutrophils, but the same number of lymphocytes and neutrophils/lymphocytes ratio. The number of eosinophils was also higher in village cats. Presumably, the higher number of leukocytes and neutrophils in a cat population with higher density is determined by the higher exchange rate of pathogens/symbionts between cats in the village than at the herdsman stations. These results may give some insight into understanding the changes in wild feline populations at different densities.
\end{abstract}

Key words: eosinophils, Felidae, immunity, mating system, neutrophils, white blood cell

\section{Introduction}

Considerable changes in our rapidly developing world and anthropogenic pressure on natural ecosystems alter the current status of many mammalian species as well as other animals. With the developing approaches to species conservation we have to take into account not only the number of individuals in a species population, but also many aspects of species biology and ecology: the changes in species range, genetic diversity, gene flow, the welfare of animals, and others (Volis et al., 2009; Game et al., 2014). The last term (individual welfare) normally corresponds to the health and hormonal status of individuals (stressed/non-stressed) and their behavioural parameters (Naidenko et al., 2011, 2019a). The immune status of the animals can be a very important parameter of their welfare. Many factors may affect individual immunity negatively: pollution (Bauer et al., 2012), food restriction (Lochmiller et al., 1993), severe environmental conditions (Novikov et al., 2015; Naidenko et al., 2019b), and pathogen colonisation/invasion (Freyberg \& Harvill, 2017).

The immune system of mammals consists of many different blocks and it is very difficult to analyse all of them to assemble data about the individual immune status. In captivity, researchers have the opportunity to test immunity to different antigens under well-controlled conditions (Novikov et al., 2010; Kuznetsova et al., 2016). In the wild, it is generally more complicated because of the field conditions, the quality and quantity of sample material obtained and difficulties with recapture. Obviously, we must minimise our own negative effect on animal health, to avoid causing injuries to the animals. It makes the choice of parameters for analysing even more complicated. The analysis of leukocytes is one of the easiest immune parameters to measure and requires only a few microliters of blood (Schneeberger et al., 2014; Pavlova et al., 2018), although it is only one of the small blocks of immunity.

Leukocytes (white blood cells) are an important part of mammalian immunity, which prevents the invasion and colonisation by different pathogens. Different types of leukocytes have different functions. Lymphocytes play an important part in both humoral and cellular adaptive immune responses (LaRosa \& Orange, 2008). Neutrophils are responsible for the phagocytosis of foreign cells (Kumar \& Sharma, 2010) as well as monocytes that may serve to neutralise larger objects (Dale et al., 2008). Eosinophils are involved in host defense against parasites and promoting allergic reactions, but also have a series of regulatory functions (Wen \& Rothenberg, 2016). The functions of basophils are still discussible but they play an important role in interleukin production and are critically involved in a wide spectrum of immunologic disorders (Marone et al., 2014).

Many factors affect the number of leukocytes and their ratio. The interspecific analysis has shown that the total number of leukocytes in rodents is 
correlated with the body mass: a larger species had more leukocytes (Tian et al., 2017). This correlation has also been described in other taxa (Nunn \& Altizer, 2004; Nunn et al., 2004; Schneeberger et al., 2013). Another important factor is the mating strategy of the species. Both in carnivores and primates the species with promiscuity as their mating strategy have a higher total leukocytes number than monogamous species (Nunn \& Altizer, 2004; Nunn et al., 2004), although the study on rodents did not show any relation between the mating system and leukocytes number (Tian et al., 2017).

The number of leukocytes in individuals of the same species may also correlate positively with their body mass (Tarakhtii et al., 2007) or body mass index (BMI) (Charles et al., 2007; Gilbert-Diamond et al., 2012). It is likely that large animals have more resources to support their immune system and to produce higher numbers of leukocytes. However, this hypothesis has never been tested in felids before. Another parameter affecting the leukocyte number was described for rodents. The number of leukocytes changed significantly over population cycles, correlated positively with the population density (Lazutkin et al., 2016). A higher population density produces a higher rate of contacts with the conspecifics (including aggressive contacts and injuries) and a higher risk of pathogen transmission. Both factors, potentially, may result in an increase of the number of leukocytes.

Felids live solitarily (Naidenko \& Erofeeva, 2004) apart from three species: lion (Panthera leo Linnaeus, 1758) (Grinell et al., 1995), cheetah (Acinonyx jubatus Schreber, 1775) (Eaton, 1970) and domestic cats (Felis catus Linnaeus, 1758) (Say et al., 2002). Ordinarily, the density of their population is not high. Although, even in these species it may vary a lot: for example, the Amur tiger (Panthera tigris altaica Temminck, 1884) population density in the Russian Far East is 0.15 individuals / $100 \mathrm{~km}^{2}$ (HernandezBlanco et al., 2015), the Indian tiger (Panthera tigris tigris Linnaeus, 1758) population density could be 11.35 individuals / $100 \mathrm{~km}^{2}$ (Narasimen et al., 2013). These populations differ in medium cortisol level (it is higher in Indian tigers (Naidenko et al., 2019a)) which in theory may affect the number of leukocytes (Davis et al., 2008; Pavlova et al., 2018) and immunity (Palacious \& Sugawara, 1982) of the animals. But it is extremely difficult to assess the effect of population density for any wild cat on the number of leukocytes. The first problem is providing the valid sample size for the analysis, which will be time-, labour- and cost-consuming for any project. However, the second problem is even more serious for the researchers: the delay between the capture and blood sampling. For almost any cat the time from the moment when the animal has been stressed (chasing, capture in the trapping boxes or leg-hold Aldrich snare) to the moment when the animal will be anesthetised exceeds one hour and affect the number and ratio of leukocytes (Pavlova et al., 2018). There are unique cases when this time can be reduced for some species of wild cats in certain habitats (Naidenko et al., 2014; Pavlova et al., 2015).

The domestic cat is the most widely distributed cat species over the world. Blood-sampling in domestic cats is a rather simple procedure and does not require immobilisation of the animals (only physical restriction is enough). It may be conducted in 3-5 min. after animal capture and does not affect the number of leukocytes and their ratio. The population density of domestic (feral) cats may vary extremely depending of food availability: from 1 individual $/ \mathrm{km}^{2}$ ) (Say et al., 2002) to 3000 cats $/ \mathrm{km}^{2}$ (Liberg \& Sandell, 1988). To sum up, among felids the most suitable species to test the hypothesis about the effect of population density on the number/ratio of leukocytes is the domestic cat. This predetermined the object choice for our study.

The aim of our study was to estimate the effect of a cat population density on the number of leukocytes in domestic cats.

\section{Material and Methods}

\section{Study area}

The study was conducted in the buffer zone of Daursky State Nature Biosphere Reserve located south of Zabaikalsky Krai near the Russian - Mongolian border $\left(50.06^{\circ} \mathrm{N}, 115.44^{\circ} \mathrm{E}\right)$. The study area covered approximately $225.9 \mathrm{~km}^{2}$ of dry mountain steppes. The annual precipitation here is $150-400 \mathrm{~mm}$ and the annual temperature fluctuation can exceed 90 ${ }^{\circ} \mathrm{C}$ (Naidenko et al., 2014). Within the study area, we explored the village Kulusutaii $\left(50.23^{\circ} \mathrm{N}, 115.68^{\circ} \mathrm{E}\right)$ and 23 herdsman stations. Forty-seven domestic cats were captured there in November 2018. The experimental design minimised the chance of capturing the reproducing females of domestic cats in this area (there were no pregnant females there and only two females had kittens about 2.5-3.5 months of age). The area of the village was $1.028 \mathrm{~km}^{2}$ and contained 164 buildings, including dwelling houses, sheds, and hangars. During the blood sampling we conducted a survey among the inhabitants about the number of cats around their households, the sex and age of the animals, the last vaccinations (no cats were vaccinated in the last three years). Based on the survey ( 34 adult cats were counted for the village), we estimated the density of adult cats as 33 individuals per $1 \mathrm{~km}^{2}$. We took 
samples from 24 cats in the village. Additionally, 23 animals were sampled at herdsman stations. The total density of cats there was 0.1 individuals $/ \mathrm{km}^{2}$. Every station was mapped with GPS (Garmin 62CSX). The mean distance between the closest herdsman stations was $4.5 \mathrm{~km}$. Free-ranging domestic cats can cover such distances easily (Naidenko \& Hupe, 2002) and can move between adjacent stations. All tested domestic cats were adults ( $>1$ year old).

\section{Sampling}

Every domestic cat was captured and handled directly by the owner. Blood samples were obtained from the femoral vein $(1-3 \mathrm{ml})$ within $5 \mathrm{~min}$ without anesthesia (physical restriction with thick gloves and clothes). After blood sampling each cat was weighed (up to $10 \mathrm{~g}$ ) with the hand scale (RST, Lund, Sweden) with the precision to $10 \mathrm{~g}$. Immediately after sampling, blood was placed into tubes with $\mathrm{K}_{3}$-EDTA buffer (Mini-collect, Greiner Bio-One, Austria).

\section{Blood preparation and analysis}

Leukocytes counting was conducted in fresh blood samples using a hemocytometer chamber (Goryaev chamber, four counting fields) under the microscope Levenhuk Rainbow 2L Plus (magnification $\times 160)$ (Levenhuk Inc., Tampa, USA) by using the standard method (Bazhibina et al., 2005). In short, the blood was diluted $1: 20 \mathrm{v} / \mathrm{v}$ with the $3.5 \%$ of acetum acid to dissolve red blood cells, $15 \mu 1$ of the solution was added to the chamber. We counted leukocytes in 100 large boxes and calculated their concentration on $1 \mathrm{ml}$ based on the hemocytometer chamber volume. The formula was:

$$
X=\frac{a \times 250 \times 20}{100}, \text { where }
$$

$X$-number of leukocytes / $\mu 1(\times 1000-$ per $1 \mathrm{ml})$;

$a$ - number of leukocytes / 100 large boxes;

20 - dilution of the blood;

100 - number of counted boxes;

250 - factor related to the volume of 1 box $(1 / 250 \mu 1)$.

Blood smears were prepared immediately, within $5 \mathrm{~min}$. after the blood sampling. Fresh blood smears were fixed in $100 \%$ methanol immediately after drying up and transferred to the lab in Moscow. The smears in the lab in Moscow were stained with Romanovsky stain according to the standard method (Bazhibina et al., 2005; Pavlova et al., 2018) shortly before the analysis. On a smear, a 100-cell differential leukocyte count was conducted manually using the microscope Leica 5000D (Leica Microsystems,
Switzerland) in the counting area (magnification $\times 1000$ ). The proportion of each leukocyte type was expressed in a percentage. The total number of white blood cells of different type (lymphocytes, neutrophils, etc.) was calculated using the following formula: absolute WBC number (counted in the field with the hemocytometer chamber) $\times$ percentage of leukocytes types / 100 .

\section{Statistical analysis}

All data are presented here as the mean with the standard error. The data on body mass, the number of leukocytes, neutrophils (N), lymphocytes (L) and eosinophils number and N/L ratio were normally distributed. We used GLM for hematological parameters with the categorical predictors «site» and "sex» and body mass as the continuous predictor. To compare other hematological parameters (the number of monocytes and basophils) between the village and shepherd cats we used the MannWhitney U test (MW) because the data distribution was different from normal.

\section{Results}

The animals in the village and in the herdsman stations differ significantly in body mass. Both «site» and «sex» factors affected the body mass of individuals significantly (FA: $\mathrm{F}=4.453 ; \mathrm{df}=1 ; \mathrm{p}=0.041$ and $\mathrm{F}=22.724 ; \mathrm{df}=1 ; \mathrm{p}=0.000$, respectively). Both males and females were significantly heavier at the herdsman stations and smaller in the village (Fig. 1). Males at the stations were about $13 \%$ and females about $9 \%$ heavier than the cats of the same sex in the village.

The «sex» of the animals had no notable effect on the number of leukocytes and their main types (neutrophils and lymphocytes). However, the "site» factor affected the number of leukocytes (GLM: $\mathrm{MS}=168.4 ; \mathrm{F}=6.788 ; \mathrm{p}=0.013)$ and neutrophils (GLM: $\mathrm{MS}=60.1 ; \mathrm{F}=6.897 ; \mathrm{p}=0.012$ ) significantly. Both indexes were higher in village cats (Fig. 2). The number of neutrophils was approximately 1.5 times higher in village cats in comparison to the cats from herdsman stations (respectively, $6.59 \pm 0.70 \mathrm{mln} / \mathrm{ml}$ and $4.33 \pm 0.46 \mathrm{mln} / \mathrm{ml})$. However, the «site» factor did not affect significantly the number of lymphocytes (GLM: MS = 15.67; $\mathrm{F}=1.96 ; \mathrm{p}=0.169$ ) (Fig. 3), although animals in the village had $30 \%$ more lymphocytes than herdsman cats. Correspondingly, the $\mathrm{N}$ : L ratio did not differ in cats of different sex and locations («site» GLM: $\mathrm{MS}=0.329 ; \mathrm{F}=0.71 ; \mathrm{p}=0.404)$. The body mass did not have significant effect on the number of leukocytes and their different types. 


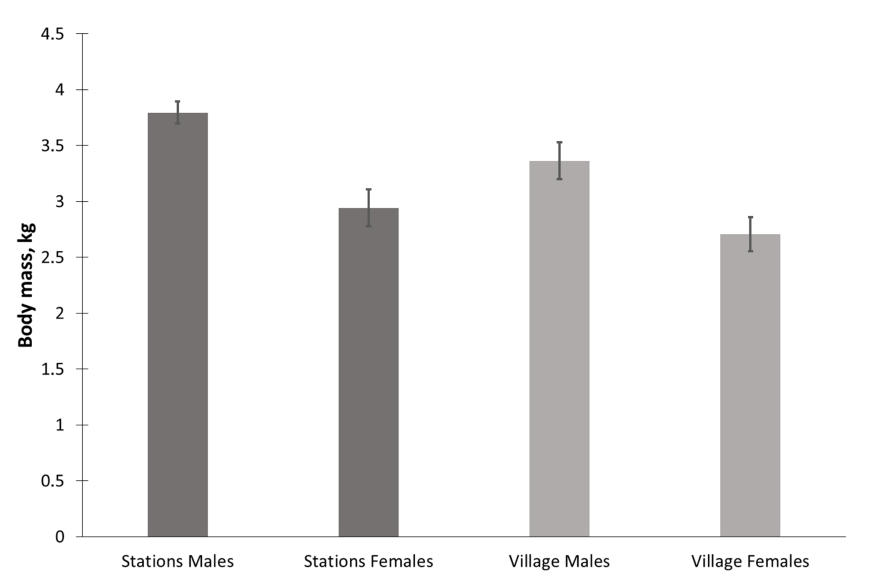

Fig. 1. The body mass of domestic cats at high (village) and low (stations) population density.

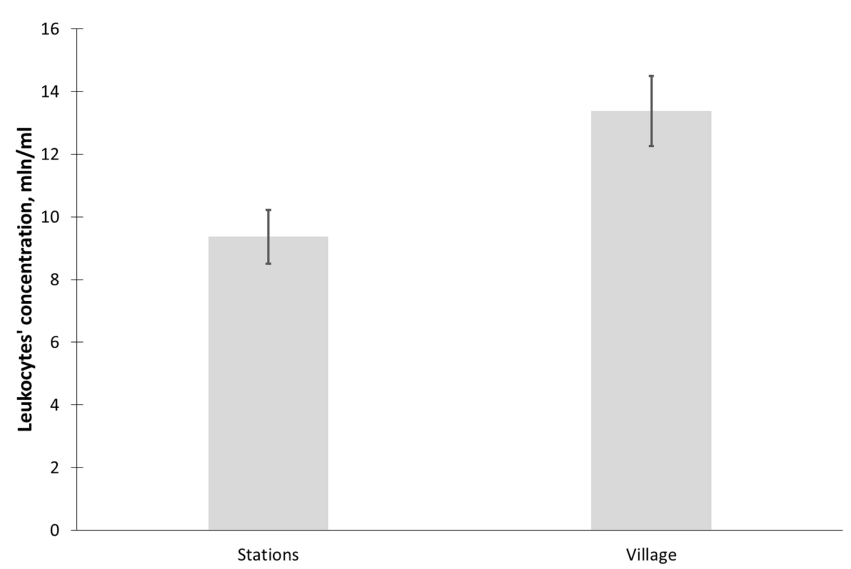

Fig. 2. The number of leukocytes in domestic cats at high (village) and low (stations) population density.

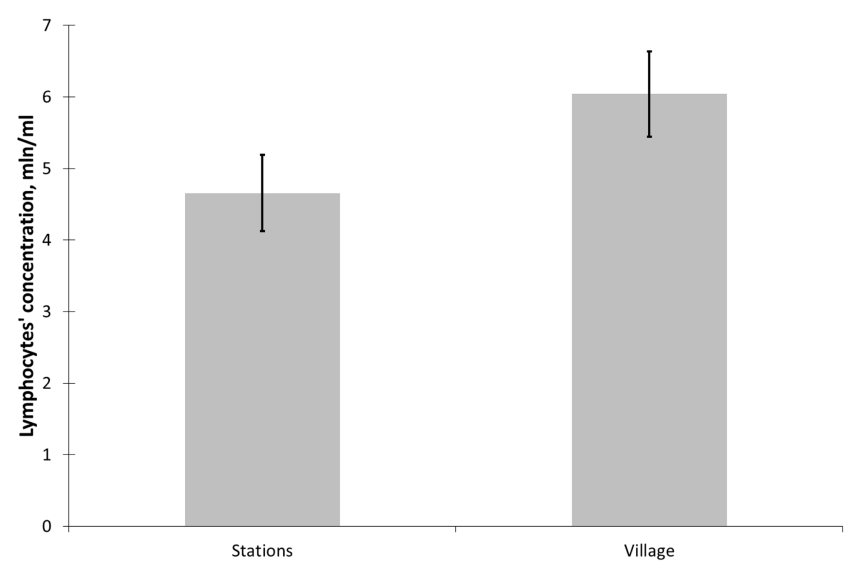

Fig. 3. The number of lymphocytes in domestic cats at high (village) and low (stations) population density.

Among minor groups of leukocytes «site» had significant effect on the number of eosinophils (GLM: $\mathrm{MS}=0.932 ; \mathrm{F}=5.556 ; \mathrm{p}=0.023$ ). Village cats had more eosinophils than herdsman cats (respectively, $0.60 \pm 0.12 \mathrm{mln} / \mathrm{ml}$ and $0.36 \pm 0.04$ $\mathrm{mln} / \mathrm{ml})$. The inter-effect of «site» and «sex» was also significant on eosinophils' this index (GLM: $\mathrm{MS}=0.799 ; \mathrm{F}=4.763 ; \mathrm{p}=0.035)$. The number of monocytes differed between these locations: village cats had fewer monocytes (MW: $U=148 ; Z=2.72$; $\mathrm{p}=0.006$ ) than herdsman cats. The numbers of basophils did not differ significantly between sites.

\section{Discussion}

The body mass of the animal affects the number of leukocytes at species level. This phenomenon has been described for several groups of mammals: rodents (Tian et al., 2017), bats (Schneeberger et al., 2013), primates (Nunn et al., 2004) and carnivores (Nunn \& Altizer, 2004). Larger species have a higher percentage of leukocytes than smaller ones. It may be explained by different hypotheses (Tian et al., 2017). However, this trend (large animals have more leukocytes), which works well enough on species level, does not seem to work on individuals. We did not find any effect of the individual body mass on the number of leukocytes (and their forms) for domestic cats in our study. In some species, the number of leukocytes was positively related with the body mass, for example, in Myodes glareolus Schreber, 1780 (Tarakhtii et al., 2007). However, more often the BMI was considered for intraspecific analysis. In humans the BMI and leukocyte number are related positively (individuals with a high BMI have more leukocytes) (Dixon \& O'Brien, 2006; Zaldivar et al., 2006; Charles et al., 2007; Gilbert-Diamond et al., 2012), however, these differences are more obvious in an obesity group. In Pan troglodytes Blumenbach, 1775 (in opposite to humans) the leukocytes number correlated negatively with the BMI (Obanda et al., 2014). However, for domestic cat scientists use score estimations instead of BMI. They are quite subjective (for example, Laflamme, 1997) and more adaptive to finding obesity in domestic pets than to estimating the status of semi-free ranging cats. The domestic cats in our study areas were never too fat; the largest male had a body mass of $4.27 \mathrm{~kg}$, the largest female $-3.58 \mathrm{~kg}$. It seems that other factors affect leukocytes number and ratio in cats in the Daursky State Nature Reserve.

Food availability is also known to be an important factor related to the number of leukocytes. Several field experiments for Sigmodon hispidus Say \& Ord, 1825 and Desmodus rotundus Wied-Neuwied, 1826 showed an increase of the number of leukocytes and $\mathrm{N}$ : L ratio respectively with the increase of food abundance (Webb et al., 2003; Becker et al., 2018). Food restriction experiments result in a decrease of immunity in mammals (Lochmiller et al., 1993; Xu \& Wang, 2010). However, although we found body mass differences in domestic cats from two study sites, we do not believe that any food restriction took place in this study. All individuals received food from 
their owners regularly and had found additional food sources in wildlife (rodents, birds and insects).

The population density may correlate negatively with the humoral immunity of mammals (Saino et al., 2000) that may be mediated by stress-response due to the contacts with the conspecifics. The fluctuations of population density showed an increase of the leukocyte number in Clethrionomys rutilus (Pallas, 1779) at the peak point (Lazutkin et al., 2016). However, in this case their number may correlate with the infection by pathogens and inflammation process before the population density crash.

In our study, the cat population was rather stable. The number of leukocytes, neutrophils and eosinophils was higher in the animals living at a higher population density. Our study site included two domestic cat «populations» with the density differing by 330 times $\left(0.1\right.$ individuals $/ \mathrm{km}^{2}$ vs. 33 individuals $\left./ \mathrm{km}^{2}\right)$. These differences in population density determine the higher rate of conspecific contacts in the village. Animals demonstrate a wide range of aggressive, amicable and olfactory contacts that may lead to an intensive pathogen exchange between the individuals. Some of the pathogens may be excreted by animals through feces, urine, saliva, vomiting, etc. and the density of such excretes in the environment will be higher in the village «population».

A higher number of contacts with the conspecifics and an exchange of potential pathogens may lead to an increase of immune tension and necessitate an increase of the number of leukocytes. Previous studies in this area showed significant differences in serum prevalence of domestic cats to several pathogens in these two study sites. For example, serum positive individuals to the feline panleukopenia virus and feline calicivirus were found significantly more often among the village cats (Pavlova et al., 2015). The number of leukocytes, neutrophils, eosinophils and lymphocytes (non-significantly) was higher in village cats than in cats living at lower population density. Only the monocytes number was lower in village cats, of which the reasons are not clear. Monocytes responsible for the extermination of relatively big pathogens and their occurrence in the village and herdsman cats were not analysed in this or previous studies (Pavlova et al., 2015, 2016).

The population density in domestic cats is closely related to the mating strategies. Domestic (feral) cats adopt different mating strategies depending on the population density. In sub-Antarctic areas (islands), where the population density is extremely low (about 1 individuals $/ \mathrm{km}^{2}$ ), they demonstrate monogamy (Say et al., 2002). In big cities where the density may be up to 3000 cats $/ \mathrm{km}^{2}$ (Liberg \& Sandell, 1988), they show promiscuity, where one female may have up to nine sexual partners (Ishida et al., 2001) and produce offspring of five different males (Say et al., 1999). We can assume (based on the population density in our studies) that the animals in the village had promiscuity and the cats at the herdsman station had fewer sexual partners than the animals in the village. A higher rate of sexual contacts and an increased number of mating partners may also change the rate of pathogen transfer and increase the number of aggressive contacts (especially for the competing males). It was not possible to distinguish the effect of population density and changes in mating system, because an increase of the population density in cats usually changes the mating strategy of the animals (from monogamy to promiscuity). Both factors contribute to an increase of contact rate and changes in leukocytes number.

We did not find any effect of the «sex» factor on the studied hematological indexes in cats. Despite males being heavier than females (which is common for felid species), the number of leukocytes, their main types and ratio were similar between sexes. In humans, women usually have more neutrophils than men (Bain, 1996). In primates, females have more lymphocytes and eosinophils than males (Nunn et al., 2009). In carnivores males have more neutrophils than females (Nunn et al., 2009). It seems that gender differences in the number of leukocytes differ significantly in each taxon and we did not observe them in this study.

To sum up, in domestic cats, living at a higher population density, we observed a higher number of leukocytes, neutrophils and eosinophils. A similar $\mathrm{N}$ : L ratio in both populations of cats did not support the idea that village cats were more stressed than the herdsman cats (Davis et al., 2008; Pavlova et al., 2018) despite their lower body mass. We assume that an increase of contacts with the conspecifics and consequences of it (pathogen transmissions, injuries during aggressive interactions, etc.) lead to an increase of the number of leukocytes (as an indicator of immunity tension) in feral cats. We did not find any effect of the body mass of animals on the number and ratio of leukocytes. It seems that this factor is only important at species level (Nunn \& Altizer, 2004; Nunn et al., 2004; Schneeberger et al., 2013; Tian et al., 2017).

It is obvious that wild cats never live at such high density as domestic cats. However, the differences in their density may also vary dramatically (by almost two orders for Amur and Indian tigers) (Narasimen et al., 2013; Hernandez-Blanco et al., 2015) and comparing immunity tension in animals of these two populations may be of interest. An increase of population den- 
sity (like, for example, three-fold in Panthera pardus orientalis Schlegel, 1857 during the last ten years (Vitkalova \& Shevtsova, 2016)) may also affect the immunity (or immunity tension) of these cats. The consequences of this phenomenon should be studied closely to predict these changes for different populations.

\section{Acknowledgements}

This study was supported by Russian Science Foundation №18-14-00200.

\section{References}

Bain B.J. 1996. Ethnic and sex differences in the total and differential white cell count and platelet count. Journal of Clinical Pathology 49(8): 664-666. DOI: 10.1136/ jcp.49.8.664

Bauer R.N., Diaz-Sanchez D., Jaspers I. 2012. Effects of air pollutants on innate immunity: The role of Tolllike receptors and nucleotide-binding oligomerization domain-like receptors. Journal of Allergy and Clinical Immunology 129(1): 14-24. DOI: 10.1016/j. jaci.2011.11.004

Bazhibina E.B., Korobov A.V., Sereda S.V., Saprykin V.P. 2005. Methodological foundations of estimation of clinic-morphological blood values of domestic animals. Moscow: Akvarium-Print. 128 p. [In Russian]

Becker D.J. Czirják G.Á., Volokhov D.V., Bentz A.B., Carrera J.E., Camus M.S., Navara K.J., Chizhikov V.E., Fenton M.B., Simmons N.B., Recuenco S.E., Gilbert A.T., Altizer S., Streicker D.G. 2018. Livestock abundance predicts vampire bat demography, immune profiles and bacterial infection risk. Philosophical transactions of the Royal Society of London. Series B, Biological Sciences 373(1745): 20170089. DOI: 10.1098/ rstb.2017.0089

Charles L.E., Fekedulegn D., McCall T., Burchfiel C.M., Andrew M.E., Violanti J.M. 2007. Obesity, white blood cell counts, and platelet counts among police officers. Obesity 15(11): 2846-2854. DOI: 10.1038/oby.2007.338

Dale D.C., Boxer L., Liles W.C. 2008. The phagocytes: neutrophils and monocytes. Blood 112(4): 935-945. DOI: 10.1182/blood-2007-12-077917

Davis A.K., Maney D.L., Maerz J.C. 2008. The use of leukocyte profiles to measure stress in vertebrates: a review for ecologists. Functional Ecology 22(5): 760-772. DOI: $10.1111 / j .1365 \_2435.2008 .01467 . x$

Dixon J.B., O'Brien P.E. 2006. Obesity and the white blood cell count: changes with sustained weight loss. Obesity Surgery 16(3): 251-257. DOI: 10.1381/096089206776116453

Eaton R.L. 1970. Group interaction, spacing and territoriality in cheetahs. Zeitschrift für Tierpsychologie 27(4): 481-491. DOI: 10.1111/j.1439-0310.1970.tb01882.x

Game E.T., Meijaard E., Sheil D., McDonald-Madden E. 2014. Conservation in a wicked complex world; chal- lenges and solutions. Conservation Letters 7(3): 271277. DOI: $10.1111 /$ conl.12050

Gilbert-Diamond D., Baylin A., Mora-Plazas M., Villamor E. 2012. Chronic inflammation is associated with overweight in Colombian school children. Nutrition $\mathrm{Me}$ tabolism and Cardiovascular Diseases 22(3): 244-251. DOI: 10.1016/j.numecd.2010.06.001

Grinell J., Packer C., Pusey A.E. 1995. Cooperation in male lions: kinship, reciprocity or mutualism? Animal Behaviour 49(1): 95-105. DOI: 10.1016/00033472(95)80157-X

Freyberg Z., Harvill E.T. 2017. Pathogen manipulation of host metabolism: a common strategy for immune evasion. PLoS Pathogens 13(12): e1006669. DOI: 10.1371/ journal. ppat.1006669

Hernandez-Blanco J.A., Naidenko S.V., Chistopolova M.D., Lukarevskiy V.S., Kostyrya A., Rybin A., Sorokin P.A., Litvinov M.N., Kotlyar A.K., Miquielle D.G., Rozhnov V.V. 2015. Social structure and space use of Amur tigers (Panthera tigris altaica) in Southern Russian Far East based on GPS telemetry data. Integrative Zoology 10(4): 365-375. DOI: 10.1111/1749-4877.12140

Ishida Y., Yahara T., Kasuya E., Yamane A. 2001. Female control of paternity during copulation: inbreeding avoidance in feral cats. Behaviour 138(2): 235-250. DOI: 10.1163/15685390151074401

Kumar V., Sharma A. 2010. Neutrophils: Cinderella of innate immune system. International Immunopharmacology 10(11): 1325-1234. DOI: 10.1016/j.intimp.2010.08.012

Kuznetsova E.V., Feoktistova N.Y., Naidenko S.V., Surov A.V., Tikhonova N.B., Kozlovskii J.E. 2016. Seasonal changes in blood cells and biochemical parameters in the Mongolian hamster (Allocricetulus curtatus). Biology Bulletin 43(4): 344-349. DOI: 10.1134/ S1062359016040087

Laflamme D.P. 1997. Development and validation of a body condition score system for cats: a clinical tool. Feline Practice 25(5/6): 13-18.

LaRosa D.F., Orange J.S. 2008. 1. Lymphocytes. Journal of Allergy and Clinical Immunology 121(2): 364-369. DOI: 10.1016/j.jaci.2007.06.016

Lazutkin A.N., Yamborko A.V., Kiselev S.V. 2016. Energy and immune parameters of northern red-backed voles (Clethrionomys rutilus) at different population densities in the Kolyma River Basin. Russian Journal of Ecology 47(6): 562-567. DOI: 10.1134/S1067413616060102

Liberg O., Sandell M. 1988. Spatial organization and reproductive tactics in the domestic cat and other feuds. In: D.C. Turner, P. Bateson (Eds.): The domestic cat: the biology of its behaviour. Cambridge: Cambridge University Press. P. 83-98.

Lochmiller R.L., Vestey M.R., McMurry S.T. 1993. Selected immune responses of adult cotton rats (Sigmodon hispidus) to dietary restriction. Comparative Biochemistry and Physiology Part A: Physiology 104(3): 593-599. DOI: 10.1016/0300-9629(93)90470-o 
Marone G., Borriello F., Varricchi G., Genovese A., Granata F. 2014. Basophils: Historical reflections and perspectives. In: C.R. Bergmann, J. King (Eds.): History of Allergy. Chemical Immunology Allergy. Vol. 100. Basel: Karger. P. 172-192. DOI: 10.1159/0003s8734

Naidenko S.V., Erofeeva M.N. 2004. Reproduction of the Eurasian lynx, Lynx lynx (Felidae, Carnivora), and the traits of female reproductive strategy. Zoologicheskii Zhurnal 83(2): 261-269. [In Russian]

Naidenko S.V., Hupe K. 2002. Seasonal changes in home range use in feral tomcats in Solling, central Germany. Zoologicheskii Zhurnal 81(11): 1371-1381. [In Russian]

Naidenko S.V., Ivanov E.A., Lukareskii V.S., HernandezBlanco J.A., Sorokin P.A., Litvinov M.N., Kotlyar A.K., Rozhnov V.V. 2011. Activity of the hypothalamopituitary-adrenals axis in the Siberian tiger (Panthera tigris altaica) in captivity and in the wild, and its dynamics throughout the year. Biology Bulletin 38: 301305. DOI: 10.1134/S1062359011030095

Naidenko S.V., Pavlova E.V., Kirilyuk V.E. 2014. Detection of seasonal weight loss and a serologic survey of potential pathogens in wild Pallas' cats (Felis [Otocolobus] manul) of the Daurian Steppe, Russia. Journal of Wildlife Diseases 50(2): 188-194. DOI: 10.7589/2013-03-068

Naidenko S.V., Berezhnoi M.A., Kumar V., Umapathy G. 2019a. Comparison of tigers' fecal glucocorticoids level in two extreme habitats. PLoS ONE 14(4): e0214447. DOI: $10.1371 /$ journal.pone.0214447

Naidenko S.V., Erofeeva M.N., Demina T.S., Alekseicheva I.A., Pavlova E.V. 2019b. Comparative estimation of some immune parameters in three felid species. Russian Journal of Theriology 18(1): 1-11. DOI: 10.15298/ rusjtheriol.18.1.01

Narasimen R.K., Kumar A.M., Jayam P.P.C., Chinnaiyan S., Nagarathinam M., Desai A.A. 2013. Status of Tigers, Co-Predators and Prey in the Wayanad Wildlife Sanctuary. Kerala, India. 60 p.

Novikov E.A., Mak V.V., Panov V.B., Moshkin M.P. 2010. A humoral immune response to non-replicated antigens and infection of red voles (Clethrionomys rutilus, Rodentia, Cricetidae) with taiga tick (Ixodes persulcatus, Acarina, Ixodidae). Zoologicheskii Zhurnal 89(1): 106114. [In Russian]

Novikov E., Kondratyuk E., Petrovski D., Krivopalov A., Moshkin M. 2015. Effects of parasites and antigenic challenge on metabolic rates and thermoregulation in northern red-backed voles (Myodes rutilus). Parasitology Research 114(12): 4479-4486. DOI: 10.1007/ s00436-015-4691-9

Nunn C.L., Altizer S.M. 2004. Sexual selection, behaviour and sexually transmitted diseases. In: P.M. Kappeler, C.P. Schaik (Eds.): Sexual selection in primates: new and comparative perspectives. Cambridge: Cambridge University Press. P. 117-130.
Nunn C.L., Gittleman J.L., Antonovics J. 2004. A comparative study of white blood cell counts and disease risk in carnivores. Proceedings. Biological Sciences 270(1513): 347-356. DOI: 10.1098/rspb.2002.2249

Nunn C.L., Lindenfors P., Pursall E.R., Rolff J. 2009. On sexual dimorphism in immune function. Philosophical transactions of the Royal Society of London. Series B, Biological Sciences 364(1513): 61-69. DOI: 10.1098/ rstb.2008.0148

Obanda V., Omondi G.P., Chiyo P.I. 2014. The influence of body mass index, age and sex on inflammatory disease risk in semi-captive chimpanzees. PLoS ONE 9(8): e104602. DOI: 10.1371/journal.pone.0104602

Palacious R., Sugawara I. 1982. Hydrocortisone abrogates proliferation of $\mathrm{T}$ cells in autologous mixed lymphocyte reaction by rendering the interleukin-2, producer $\mathrm{T}$ cells unresponsive to interleukin-1 and unable to synthesize the T-cell growth factor. Scandinavian Journal of Immunology 15(1): 25-31. DOI: 10.1111/ j.1365-3083.1982.tb00618.x

Pavlova E.V., Kirilyuk V.E., Naidenko S.V. 2015. Patterns of seroprevalence of feline viruses among domestic cats (Felis catus) and Pallas' cats (Otocolobus manul) in Daursky Reserve, Russia. Canadian Journal of Zoology 93(11): 849-855. DOI: 10.1139/cjz-2015-0006

Pavlova E.V., Kirilyuk V.E., Naidenko S.V. 2016. Occurrence pattern of influenza A virus, Coxiella burnetii, Toxoplasma gondii, and Trichinella sp. in the Pallas cat and domestic cat and their potential prey under arid climate conditions. Arid Ecosystems 6(4): 277-283. DOI: 10.1134/S2079096116040089

Pavlova E.V., Alekseeva G.S., Erofeeva M.N., Vasilieva N.A., Tchabovsky A.V., Naidenko S.V. 2018. The method matters: The effect of handling time on cortisol level and blood parameters in wild cats. Journal of Experimental Zoology Part A: Ecological and Integrative Physiology 329(3): 112-119. DOI: 10.1002/jez.2191

Saino N., Canova L., Fasola M., Martinelli R. 2000. Reproduction and population density affect humoral immunity in bank voles under field experimental conditions. Oecologia 124: 358-366. DOI: 10.1007/ s004420000395

Say L., Devillard S., Natoli E., Pontier D. 2002. The mating system of feral cats (Felis catus L.) in a subAntarctic environment. Polar Biology 25(11): 838-842. DOI: 10.1007/s00300-002-0427-2

Say L., Pontier D., Natoli E. 1999. High variation in multiple paternity of domestic cats (Felis catus L.) in relation to environmental conditions. Proceedings. Biological Sciences 266(1433): 2071-2074. DOI: 10.1098/rspb.1999.0889

Schneeberger K., Czirják G.A., Voigt C.C. 2013. Measures of the constitutive immune system are linked to diet and roosting habits of Neotropical bats. PLOS ONE 8(1): e54023. DOI: 10.1371/journal.pone.0054023 
Schneeberger K., Courtiol A., Czirják G.A., Voigt C.C. 2014. Immune profile predicts survival and reflects senescence in a small, long-lived mammal, the greater sac-winged bat (Saccopteryx bilineata). PLoS ONE 9(9): e108268. DOI: 10.1371/journal. pone. 0108268

Tarakhtii E.A., Davydova Yu.A., Kshnyasev I.A. 2007. Annual variation in hematological indices in a fluctuating population of bank vole (Clethrionomys glareolus). Biology Bulletin 34(6): 635-643. DOI: 10.1134/ S1062359007060155

Tian J., Courtiol A., Schneeberger K., Greenwood A.D., Czirják G.A. 2017. Circulating white blood cell counts in captive and wild rodents are influenced by body mass rather than testes mass, a correlate of mating promiscuity. Functional Ecology 29(6): 823-829. DOI: 10.1111/1365-2435.12394

Vitkalova A.V., Shevtsova E.I. 2016. A complex approach to study the Amur leopard using camera traps in Protected Areas in the southwest of Primorsky Krai (Russian Far East). Nature Conservation Research 1(3): 53-58. DOI: $10.24189 /$ ncr.2016.027
Volis S., Blecher M., Sapir Y. 2009. Complex ex situ - in situ approach for conservation of endangered plant species and its application to Iris atrofusca of the Northern Negev. BioRisk 3: 137-160. DOI: 10.3897/biorisk.3.5

Webb R.E., Leslie Jr. D.M., Lochmiller R.L., Masters R.E. 2003. Immune function and hematology of male cotton rats (Sigmodon hispidus) in response to food supplementation and methionine. Comparative Biochemistry and Physiology Part A: Molecular \& Integrative Physiology 136(3): 577-589. DOI: 10.1016/S1095-6433(03)00209-5

Wen T., Rothenberg M.E. 2016. The regulatory function of eosinophils. Microbiology Spectrum 4(5): MCHD-00202015. DOI: 10.1128/microbiolspec.MCHD-0020-2015

Xu D.L., Wang D.H. 2010. Fasting suppresses T cell-mediated immunity in female Mongolian gerbils (Meriones unguiculatus). Comparative Biochemistry and Physiology Part A: Molecular \& Integrative Physiology 155(1): 25-33. DOI: 10.1016/j.cbpa.2009.09.003

Zaldivar F., McMurray R.G., Nemet D., Galassetti P., Mills P.J., Cooper D.M. 2006. Body fat and circulating leukocytes in children. International Journal of Obesity 30(6): 906-911. DOI: 10.1038/sj.ijo.0803227

\title{
ВЛИЯНИЕ ПЛОТНОСТИ ПОПУЛЯЦИИ НА ЧИСЛО ЛЕЙКОЦИТОВ У ДОМАШНИХ КОШЕК
}

\author{
С. В. Найденко ${ }^{1, *}$, П. С. Ключникова ${ }^{1}$, В. Е. Кирилюк ${ }^{1,2}$, Г. С. Алексеева ${ }^{1}$ \\ ${ }^{1}$ Институт проблем экологии и эволючии им. А.Н. Севериова РАН, Россия \\ ${ }^{2}$ Государственный природный биосферный заповедник «Даурский», Россия \\ *e-mail: snaidenko@mail.ru
}

\begin{abstract}
Лейкоциты - важная часть иммунной системы млекопитающих, которая предотвращает проникновение в организм и размножение различных патогенов. Значительное число факторов влияет на число лейкоцитов у млекопитающих, в том числе и плотность популяции. Плотность популяций у одного и того же вида кошачьих может варьировать в 100-300 раз. И целью настоящего исследования было оценить влияние этого фактора на число лейкоцитов и их соотношение в двух группировках домашних кошек (Felis catus) с различной плотностью популяций. Мы собрали пробы от 47 кошек в окрестностях государственного природного заповедника «Даурский», подсчитали под микроскопом число лейкоцитов вскоре после сбора проб, а позднее в лаборатории определили лейкоцитарную формулу на мазках. Плотность популяций/группировок кошек в деревне и на пастушьих стоянках различалась примерно в 330 раз. У домашних кошек в деревне (в группировке с более высокой плотностью) было больше лейкоцитов и нейтрофилов. Однако, число лимфоцитов и соотношение нейтрофилов и лимфоцитов не отличалось достоверно. Число эозинофилов было также выше у кошек в деревне. Предположительно, большее число лейкоцитов и нейтрофилов в популяции кошек с более высокой плотностью вызвано более высокой скоростью обмена патогенами/симбионтами между кошками в деревне по сравнению с кошками с пастушьих стоянок. Эти результаты могут дать идеи для понимания изменений в популяциях диких кошачьих различной плотности.
\end{abstract}

Ключевые слова: иммунитет, кошачьи, лейкоциты, нейтрофилы, система спариваний, эозинофилы 